\title{
Global Warming Potential of Organic Strawberry Production under Unheated High Tunnels in Kentucky, USA
}

\author{
Sean Clark ${ }^{1, *(D)}$ and Seyed Hashem Mousavi-Avval ${ }^{2,3}$ \\ 1 Department of Agriculture \& Natural Resources, Berea College, Berea, KY 40404, USA \\ 2 USDA Forest Products Laboratory, Madison, WI 53726, USA; mousaviavval@wisc.edu \\ 3 Department of Biological Systems Engineering, University of Wisconsin-Madison, Madison, WI 53706, USA \\ * Correspondence: clarks@berea.edu
}

check for updates

Citation: Clark, S.; Mousavi-Avval, S.H. Global Warming Potential of Organic Strawberry Production under Unheated High Tunnels in Kentucky, USA. Sustainability 2022, 14, 1778. https://doi.org/ $10.3390 /$ su14031778

Academic Editor: Domenico Ronga

Received: 6 January 2022

Accepted: 2 February 2022

Published: 4 February 2022

Publisher's Note: MDPI stays neutral with regard to jurisdictional claims in published maps and institutional affiliations.

Copyright: (C) 2022 by the authors. Licensee MDPI, Basel, Switzerland. This article is an open access article distributed under the terms and conditions of the Creative Commons Attribution (CC BY) license (https:// creativecommons.org/licenses/by/ $4.0 /)$.

\begin{abstract}
The global warming potential (GWP) of organic strawberries (Fragaria $\times$ ananassa) grown under high tunnels in Kentucky, USA, was assessed using life cycle assessment (LCA) methodology. The site, part of the Berea College Farm, had been under organic crop management for two decades. The GWP was calculated as $0.57 \mathrm{~kg} \mathrm{CO}$-eq per $\mathrm{kg}$ of strawberries with the combined impact of the aluminum and plastic manufacturing accounting for $44 \%$ of the total and the direct production activities, including labor, accounting for another $28 \%$. The average yields of $18,990 \mathrm{~kg} / \mathrm{ha}$ of fresh fruit over the two years (2020-2021) were comparable to those typically reported in the southeastern USA for conventional production, but opportunities to increase strawberry yields in high tunnels without increasing inputs should be explored to reduce the GWP. Future research should also measure the GWP of production in controlled-environment agriculture (CEA) systems, particularly plant factories with artificial lighting (PFALs), to compare the greenhouse gas emissions of strawberries grown with these technologies to those produced using the simple, high-tunnel method.
\end{abstract}

Keywords: strawberry; organic; greenhouse gas emissions; life cycle assessment; high tunnel

\section{Introduction}

Strawberries (Fragaria $\times$ ananassa) are among the most popular fresh fruits in the United States (USA), ranking behind only a few others, such as apples and bananas, in annual per capita consumption. Production has steadily increased to meet consumer demand, and the USA leads the world in strawberry production [1]. However, most commercial production is concentrated in California, with Florida a distant second. These two states, along with North Carolina and Oregon, account for about $99 \%$ of all domestic production [2], and imports from Mexico supply most of the remaining consumer market demand. Despite this imbalanced production situation, opportunities exist for small-scale producers throughout the USA to grow and sell strawberries as demand for local and organic products continues to rise [3].

The Berea College Farm, the oldest continuously operating student educational farm in the US [4], has produced strawberries on a small scale for decades. The practices and systems used have evolved, just as they have across the entire strawberry industry. While perennial matted row culture was the norm two decades ago, the farm shifted to certified organic, annual hill production with cover-cropped furrows/paths about a decade ago (Figure 1a). This system also used floating row covers and drip-tape irrigation under the plastic mulch. The cover crop was flattened to create mulched paths that minimized muddy conditions for harvesters and kept the fruit cleaner. Nevertheless, harvested amounts and quality were highly dependent upon weather conditions.

Over the past several years, the farm has transitioned to growing certified organic strawberries using annual hill production in unheated high tunnels [5] with woven plastic fabric for weed management (Figure 1b). The plants are "Chandler" and "Ruby June" 
established from certified organic plugs sourced from North Carolina. This system has generated higher fruit yields with fewer blemishes and longer shelf life. This approach is highly compatible with seasonal direct marketing to consumers interested in fresh, local, organic products. Most of the practices and inputs could also be suitable for and appealing to small-scale conventional operations in the region because of the potential savings in herbicide and fungicide expenses with the polyethylene protection above and the weed barrier on the ground. Of course, the high-tunnel structure is a relatively large investment for a small area that should be used and amortized over many years to justify the investment. Production costs and profitability are critical considerations for any producer, but they are not the only concerns.

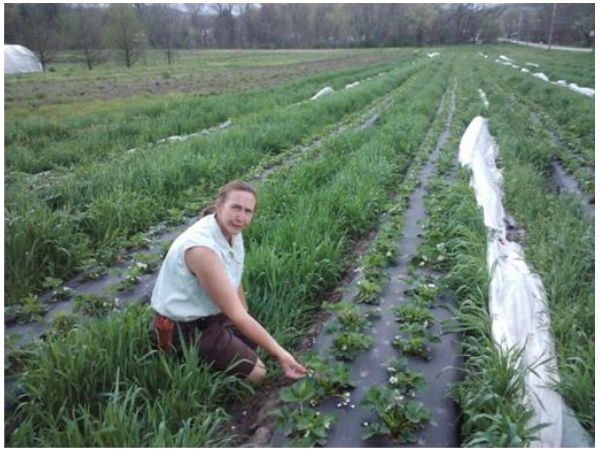

(a)

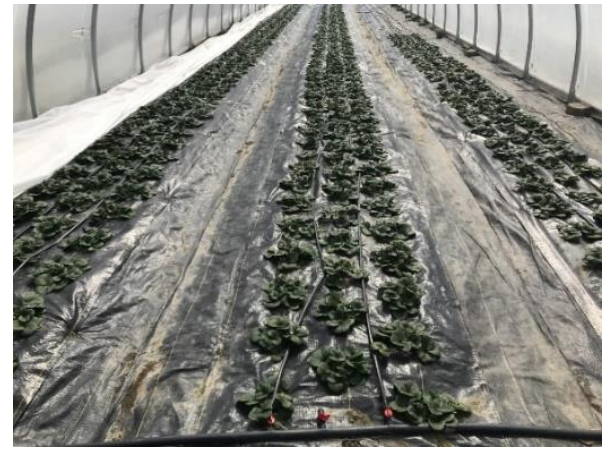

(b)

Figure 1. Berea College Farm has produced certified organic strawberries as annuals over the past decade using two systems: (a) outdoors on raised beds with black plastic mulch and rye (Secale cereale) as a cover crop and mulch between the beds to protect soil and build organic matter, and more recently, (b) on beds in unheated high tunnels with woven weed fabric.

Increasing public interest in the environmental impacts of food, particularly related to climate change, means that producers are giving more attention to assessing, improving, and communicating their performance to consumers [6-8]. In their recent overview of the strawberry industry in the USA, Samtani et al. [3] discussed the various major factors affecting production today, including the loss of methyl bromide as a soil fumigant, restrictions of pesticides, challenges of finding labor, and China's ban on importing used plastics for recycling. They predicted that "[o]rganic berry production is likely to increase in the future with increasing consumer demand and the consumer's willingness to pay a premium price for organically grown produce". This presents opportunities for small producers willing to pursue organic certification. However, the authors also anticipated an expansion of controlled-environment agriculture (CEA) for strawberry where "fruit can be produced close to population centers and transportation costs are low".

These expected trends raise some interesting and important questions about the environmental performance of different strawberry production systems, particularly with respect to carbon emissions. Tabatabaie and Murthy [2] used life cycle assessment (LCA) methodology to compare the environmental performance of strawberry production in California, Florida, Oregon, and North Carolina and found that strawberries produced in California had the lowest impacts according to most metrics due to the extremely high yields relative to other regions. More specifically, they reported that the global warming potential (GWP) of strawberries produced in California, Oregon, Florida, and North Carolina was $1.75,2.21,2.50$, and $5.48 \mathrm{~kg} \mathrm{CO}_{2}$-eq per kilogram of strawberry, respectively. Transportation impacts were not included, but a widely cited study by Weber and Matthews [9] reported that "food miles" for delivery to the consumer account for only 11\% of greenhouse gas (GHG) emissions for fruits and vegetables in the US food system. Most of the impact results from actual production-specifically the material inputs and production practices used.

A better understanding is needed of the environmental impacts of strawberries grown using different management practices and inputs, such as organic production in high 
tunnels as well as large-scale CEA systems. A very wide range of strawberry yields per unit area has been reported in the literature from around the world (Table 1), suggesting the potential for substantial yield increases that could result not only in higher productivity but also reductions in land use. However, questions remain about the net GHG emissions associated with these high yields generated from protected systems, such as plant factories with artificial lighting (PFALs) and tunnels.

Table 1. Strawberry yields reported in the literature from various geographic locations and under different production methods.

\begin{tabular}{|c|c|c|c|c|}
\hline $\begin{array}{l}\text { Open Field or } \\
\text { Protected }\end{array}$ & $\begin{array}{l}\text { Conventional or } \\
\text { Organic }\end{array}$ & Location & Source & Yield (kg/ha) \\
\hline Greenhouse-in peat & Conventional & Western Germany & Soode-Schimonsky et al. [10] & 100,000 \\
\hline Open field & Conventional & California, USA & Samtani et al. [3] & 96,047 \\
\hline Greenhouse & Conventional & Turkey & Yildizhan [11] & 75,063 \\
\hline Poly-Tunnel-in peat & Conventional & Western Germany & Soode-Schimonsky et al. [10] & 75,000 \\
\hline Open field & Conventional & California, USA & Tabatabaie and Murthy [2] & 74,000 \\
\hline Greenhouse & Conventional & Iran & Khoshnevisan et al. [12] & 72,512 \\
\hline Open field & Conventional & USA & Wu et al. [1] & 46,558 \\
\hline Open field & Conventional & Spain & Mordini et al. [13] & 32,802 \\
\hline Greenhouse & Organic & Italy & Tittarelli et al. [14] & 30,000 \\
\hline Open field & Conventional & Florida, USA & Samtani et al. [3] & 28,249 \\
\hline Open field & Conventional & Italy & Valianate et al. [15] & 26,500 \\
\hline "Protected" - in coir & Conventional & United Kingdom & Mordini et al. [13] & 22,900 \\
\hline Open field & Conventional & Western Germany & Soode-Schimonsky et al. [10] & 22,000 \\
\hline Open field & Conventional & South Carolina, USA & Samtani et al. [3] & 21,299 \\
\hline "Protected" - in peat & Conventional & United Kingdom & Mordini et al. [13] & 20,450 \\
\hline "Protected"—in soil & Conventional & United Kingdom & Mordini et al. [13] & 19,318 \\
\hline Open field & Conventional & Switzerland & Valianate et al. [15] & 18,400 \\
\hline Open field & Conventional & Virginia, USA & Samtani et al. [3] & 16,142 \\
\hline Open field & Conventional & United Kingdom & Mordini et al. [13] & 15,117 \\
\hline Open field & Conventional & North Carolina, USA & Samtani et al. [3] & 13,452 \\
\hline Open field & Conventional & Alabama, USA & Samtani et al. [3] & 11,787 \\
\hline Open field & Conventional & Northeast, USA & Samtani et al. [3] & 11,210 \\
\hline Open field & Conventional & Upper Midwest, USA & Samtani et al. [3] & 7847 \\
\hline Open field-in peat & Conventional & United Kingdom & Mordini et al. [13] & 7100 \\
\hline Open field & Conventional & Southern Estonia & Soode-Schimonsky et al. [10] & 7000 \\
\hline Open field & Conventional & Southern Estonia & Soode-Schimonsky et al. [10] & 5500 \\
\hline Open field & Conventional & Iran & Khoshnevisan et al. [12] & 5476 \\
\hline Open field & Organic & Western Estonia & Soode-Schimonsky et al. [10] & 5000 \\
\hline Open field & Organic & Southern Estonia & Soode-Schimonsky et al. [10] & 3000 \\
\hline
\end{tabular}

Clearly, the results from Tabatabaie and Murthy [2] suggest that high yields from openfield production systems in California have superior performance over other commercial production systems. However, when yields like these are obtained using greenhouses and tunnels, what are the GHG emissions per unit of output and how do they compare with other productions systems? Table 2 presents a summary of findings about the GWP of strawberry production, presented as the GHG emissions $\left(\mathrm{kg} \mathrm{CO}_{2}-\mathrm{eq}\right)$ per $\mathrm{kg}$ of strawberries produced. The lowest rates of GHG emissions are from countries in the Mediterranean region, such as Spain, Italy, and Turkey, using either open-field or tunnel production systems. By contrast, the highest emissions are from open-field and greenhouse production systems in the USA, Germany, United Kingdom, and Japan. The objective of this research was to provide a transparent assessment of the GWP of small-scale, organic strawberry production using unheated high tunnels in central Kentucky, USA. 
Table 2. Greenhouse gas emissions reported for strawberry production (per kg of fruit produced) reported in the literature from various geographic locations and under different production methods.

\begin{tabular}{|c|c|c|c|c|}
\hline Production System & Location & $\begin{array}{l}\text { GHG } \\
\text { Emissions } \\
\left(\mathrm{kg} \mathrm{CO}_{2} \text {-eq) }\right.\end{array}$ & Source & Scope \\
\hline Open field & N. Carolina & 5.48 & Tabatabaie and Murthy [2] & Cradle-to-gate \\
\hline Greenhouse & Japan & 3.99 & Mordini et al. [13] & Cradle-to-gate \\
\hline Open field & Florida & 2.50 & Tabatabaie and Murthy [2] & Cradle-to-gate \\
\hline Greenhouse, peat bag & Germany & 2.50 & Soode et al. [16] & Cradle-to-grave \\
\hline Open field & Oregon & 2.21 & Tabatabaie and Murthy [2] & Cradle-to-gate \\
\hline Open field & Germany & 1.87 & Valianate et al. [15] & Cradle-to-gate \\
\hline Open field & California & 1.75 & Tabatabaie and Murthy [2] & Cradle-to-gate \\
\hline Open field & United Kingdom & 1.20 & Mordini et al. [13] & Cradle-to-gate \\
\hline Open field & Spain & 0.88 & Mordini et al. [13] & Cradle-to-grave \\
\hline $\begin{array}{l}\text { High tunnel-integrated, } \\
\text { soilless }\end{array}$ & Spain & 0.87 & Romero-Gámez and Suárez-Rey [17] & Cradle-to-gate \\
\hline Open field-conv. & Spain & 0.83 & Romero-Gámez and Suárez-Rey [17] & Cradle-to-gate \\
\hline Greenhouse & Iran & 0.70 & Khoshnevisan et al. [12] & Cradle-to-gate \\
\hline Open field & Iran & 0.59 & Khoshnevisan et al. [12] & Cradle-to-gate \\
\hline Greenhouse & Turkey & 0.51 & Yildizhan [11] & Cradle-to-gate \\
\hline Open field & Germany & 0.40 & Soode et al. [16] & Cradle-to-grave \\
\hline Open field & Turkey & 0.24 & Yildizhan [11] & Cradle-to-gate \\
\hline High tunnel-conv. & Spain & 0.23 & Romero-Gámez and Suárez-Rey [17] & Cradle-to-gate \\
\hline High tunnel-integrated & Spain & 0.22 & Romero-Gámez and Suárez-Rey [17] & Cradle-to-gate \\
\hline Open field & Italy & 0.21 & Valianate et al. [15] & Cradle-to-gate \\
\hline Low-tunnel-conv. & Spain & 0.21 & Romero-Gámez and Suárez-Rey [17] & Cradle-to-gate \\
\hline Low tunnel—integrated & Spain & 0.21 & Romero-Gámez and Suárez-Rey [17] & Cradle-to-gate \\
\hline High tunnel—conv., soilless & Spain & 0.12 & Romero-Gámez and Suárez-Rey [17] & Cradle-to-gate \\
\hline High tunnel—organic & Spain & 0.11 & Romero-Gámez and Suárez-Rey [17] & Cradle-to-gate \\
\hline
\end{tabular}

\section{Materials and Methods}

\subsection{Production System}

This study consisted of a cradle-to-farmgate LCA of certified organic strawberries produced in an unheated high tunnel. The LCA was conducted by following the ISO 14040 and ISO 14044 standards [18,19]. The functional unit was considered to be $1 \mathrm{~kg}$ of strawberry fruit, and the system boundaries were defined as presented in Figure 2. The input and output data used to generate the inventory were collected from organic strawberry production in high tunnels at the Berea College Farm in Berea, Kentucky, USA, using management and harvest records from the 2020 and 2021 production years, interviews with the farm manager responsible for the enterprise, and field measurements.

The site had been managed using organic practices according to USDA National Organic Program for 20 years and produced a wide range of vegetables and fruits annually using high tunnels $[20,21]$. Each high tunnel measured 30 by $6 \mathrm{~m}$ ( 95 by $20 \mathrm{ft}$ ) and consisted of an aluminum frame covered with attached clear polyethylene sheeting. Plants were grown directly in the soil, which was routinely amended with composts and commercial organic fertilizers. All of the high tunnels were equipped with drip irrigation and were opened and closed manually for ventilation as needed.

Strawberries occupied one or two of the eight high tunnels at the farm in any given year and required 10-11 months to complete a cycle, from transplanting to clean-up after the harvest. Woven, plastic landscaping fabric was used to cover the entire ground surface within a high tunnel before transplanting. Prior to putting the fabric down in the high tunnel for the first time, holes were burned into it with a propane torch with spacings of $30 \mathrm{~cm}$ (12 in) between each row on a bed and $35 \mathrm{~cm}$ (14 in) between plants within a row. Certified organic strawberry plugs were purchased and shipped from a nursery in North Carolina in September of each year and planted into three rows on each of three beds in each high tunnel (Figure 1b). Two lines of irrigation drip tape were positioned on each bed 
between the rows. During the winter, the beds were covered with floating row cover for additional protection. Harvests began in late April and continued through early June in both years. In 2020, the strawberry cultivar "Chandler" was grown; in 2021, "Ruby June" was grown.

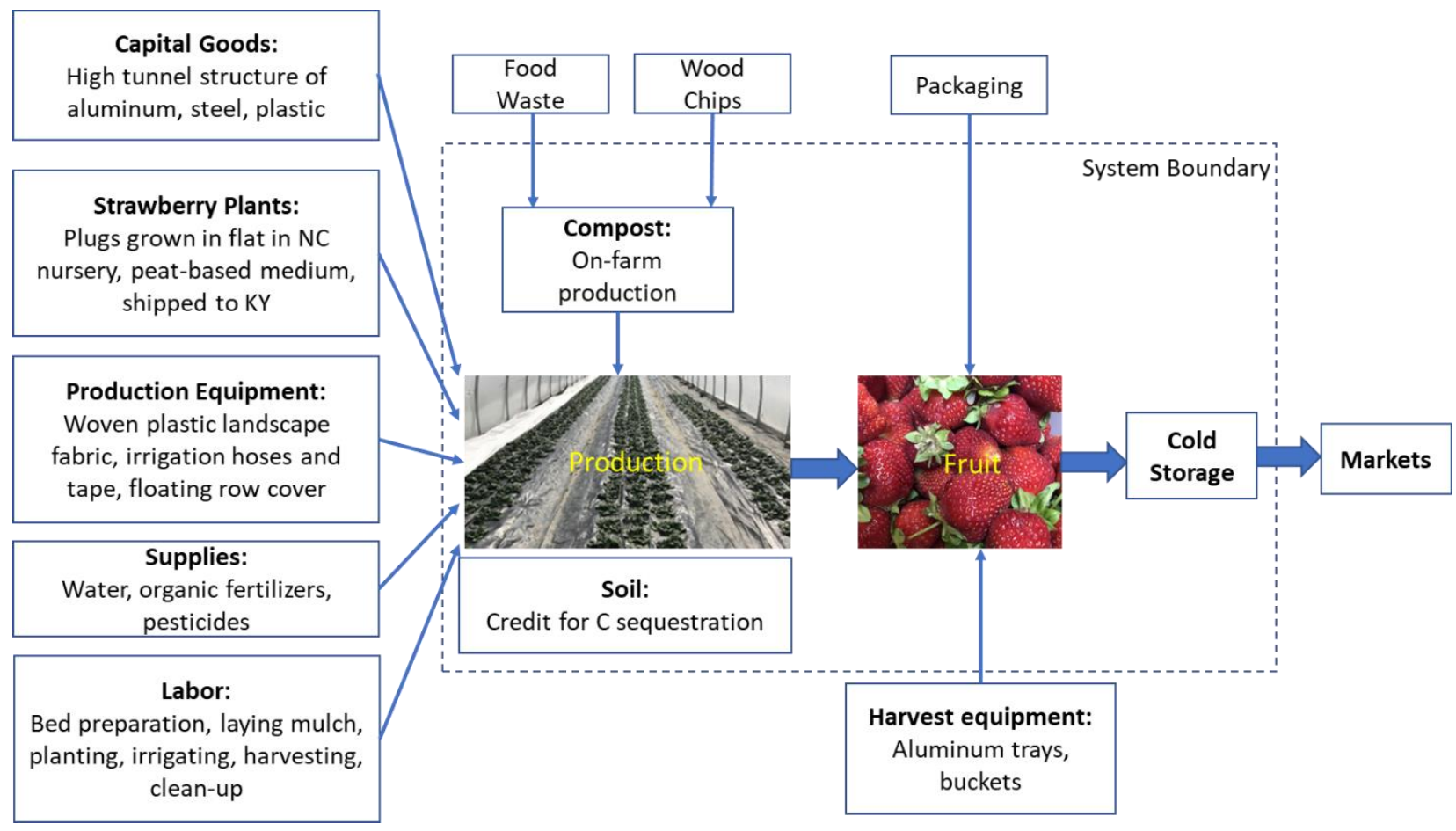

Figure 2. A flow-chart diagram illustrating the inputs and outputs of organic, high-tunnel strawberry production on the Berea College Farm.

\subsection{Life Cycle Assessment}

The life cycle inventory data consisted of all materials consumed, energy inputs, equipment and facilities used, direct emissions associated with the production, harvest and post-harvest operations, as well as the yields of strawberries harvested and sold during the two years. The amount of carbon annually sequestered in the soil was estimated from soil test data collected in the top $15 \mathrm{~cm}$ over a 20-year period. All soil analyses were performed by A\&L Western Agricultural Laboratories (Modesto, CA, USA). Direct emissions associated with the production, harvest, and post-harvest were estimated by following the method suggested by the Intergovernmental Panel on Climate Change (IPCC) [22].

The inventory data were subjected to SimaPro 9.1.1 modeling software [23] using the DataSmart database [24], which effectively represents the USA in processes for energy, materials, and wastes. The Tools for the Reduction and Assessment of Chemical and other Environmental Impacts (TRACI) impact category method [25] was used for environmental impact assessment. The GWP, which is a standardized index of the overall amount of heat absorbed as a result of the direct and indirect GHG emissions of an action or product, is presented as $\mathrm{kg} \mathrm{CO}_{2}$-eq per $\mathrm{kg}$ of marketable strawberry fruit harvested and sold.

\section{Results and Discussion}

\subsection{Crop Yield}

An inventory of inputs for high-tunnel strawberry production on the Berea College Farm is presented in Table 3. This inventory was generated using farm production and harvest records, a physical inventory, and published enterprise budgets produced by landgrant universities to verify and confirm values. A single season of strawberry production utilizes the space of a high tunnel for nearly one year (10-11 months) when pre-planting 
soil preparation and post-harvest clean-up are included. Thus, the season typically begins in early September and ends in early July of the following year. A flow-chart diagram illustrates the process, system boundaries, inputs, and outputs in Figure 2.

Table 3. Inventory of inputs and outputs for a life cycle assessment of high-tunnel strawberry production (outer footprint $=176.5 \mathrm{~m}^{2}$ or $1900 \mathrm{ft}^{2}$ ) on the Berea College Farm.

\begin{tabular}{|c|c|c|c|c|}
\hline Category & Material/Activities & $\begin{array}{l}\text { Quantity/High } \\
\text { Tunnel }\end{array}$ & Unit & $\begin{array}{l}\text { Lifespan } \\
\text { (Years) }\end{array}$ \\
\hline \multirow[t]{4}{*}{ Capital Goods } & Aluminum structure & 1036 & $\mathrm{~kg}$ & 30 \\
\hline & Steel screws, wire, and hydrant & 20 & $\mathrm{~kg}$ & 30 \\
\hline & Plastic (6 mil poly plastic) & 47 & $\mathrm{~kg}$ & 5 \\
\hline & Plastic (PVC water line to tunnel) & 14 & $\mathrm{~kg}$ & 20 \\
\hline \multirow{4}{*}{$\begin{array}{l}\text { Strawberry } \\
\text { Plants }\end{array}$} & Plastic trays with cells & 4 & $\mathrm{~kg}$ & 3 \\
\hline & Peat-based potting medium & 6 & $\mathrm{~kg}$ & 1 \\
\hline & Plants & 14 & $\mathrm{~kg}$ & 1 \\
\hline & Transportation from NC & 470 & $\mathrm{~km}$ & 1 \\
\hline \multirow{8}{*}{$\begin{array}{l}\text { Production } \\
\text { Equipment }\end{array}$} & Woven plastic landscape fabric & 9 & $\mathrm{~kg}$ & 5 \\
\hline & Irrigation header line (plastic) & 7 & $\mathrm{~kg}$ & 5 \\
\hline & Irrigation drip tape (plastic) & 2 & $\mathrm{~kg}$ & 2 \\
\hline & Irrigation valves & 1 & $\mathrm{~kg}$ & 2 \\
\hline & $\begin{array}{l}\text { Spun polyester row-cover fabric } \\
\text { (row cover) }\end{array}$ & 10 & $\mathrm{~kg}$ & 4 \\
\hline & $\begin{array}{l}\text { Steel ground staples (to pin } \\
\text { landscape fabric) }\end{array}$ & 1 & $\mathrm{~kg}$ & 5 \\
\hline & Two-wheel tractor with rotary plow & 2 & hour & 1 \\
\hline & Propane burner & 3 & hour & 1 \\
\hline \multirow[t]{4}{*}{ Supplies } & Water & 60,567 & 1 & 1 \\
\hline & $\begin{array}{l}\text { Organic fertilizer-Nature Safe } \\
13-0-0\end{array}$ & 14 & $\mathrm{~kg}$ & 1 \\
\hline & $\begin{array}{l}\text { Gasoline (two-wheel tractor with } \\
\text { rotary plow) }\end{array}$ & 4 & 1 & 1 \\
\hline & Propane (burner) & 4 & 1 & 1 \\
\hline \multirow[t]{8}{*}{ Labor } & Bed preparation (two-wheel tractor) & 2 & hour & 1 \\
\hline & Compost application & 3 & hour & 1 \\
\hline & Burning holes in landscape fabric & 1 & hour & 1 \\
\hline & $\begin{array}{l}\text { Laying and pinning landscaping } \\
\text { fabric }\end{array}$ & 2 & hour & 1 \\
\hline & Planting & 32 & hour & 1 \\
\hline & Irrigating & 4 & hour & 1 \\
\hline & Harvesting & 90 & hour & 1 \\
\hline & Clean-up & 16 & hour & 1 \\
\hline \multirow[t]{2}{*}{$\begin{array}{l}\text { Harvest } \\
\text { Equipment }\end{array}$} & Aluminum trays & 3 & $\mathrm{~kg}$ & 10 \\
\hline & Plastic buckets & 2 & $\mathrm{~kg}$ & 2 \\
\hline Packaging & Plastic retail container & 19 & $\mathrm{~kg}$ & 1 \\
\hline Compost & $\begin{array}{l}\text { Compost-from food waste and } \\
\text { wood chips }\end{array}$ & 91 & $\mathrm{~kg}$ & 1 \\
\hline Cold Storage & $\begin{array}{l}\text { Cold storage (electricity to operate } \\
\text { air conditioner) }\end{array}$ & 12 & hour & 1 \\
\hline Soil & Carbon sequestration $\left(\mathrm{CO}_{2}\right.$-eq in $\left.\mathrm{lbs}\right)$ & $(15)$ & $\mathrm{kg}$ & 1 \\
\hline \multirow[t]{2}{*}{ Output } & Strawberry yield "Chandler" (2020) & 327 & $\mathrm{~kg}$ & 1 \\
\hline & Strawberry yield "Ruby June" (2021) & 343 & $\mathrm{~kg}$ & 1 \\
\hline
\end{tabular}

The strawberry fruit harvested per high tunnel in 2020 ("Chandler") was $327 \mathrm{~kg}$ and in 2021 ("Ruby June") was $343 \mathrm{~kg}$, for an average output of $335 \mathrm{~kg}$. This is equivalent to $18,990 \mathrm{~kg} / \mathrm{ha}$ for comparison with other studies. There is a more than a 30 -fold difference between the highest and lowest strawberry yields reported in the literature (Table 1). The average yield in this study was lower than the average reported for the USA and the world 
(Figure 3). However, it is comparable to typical yields reported for adjacent states in the southeastern USA, such as Virginia and North Carolina (Table 1).

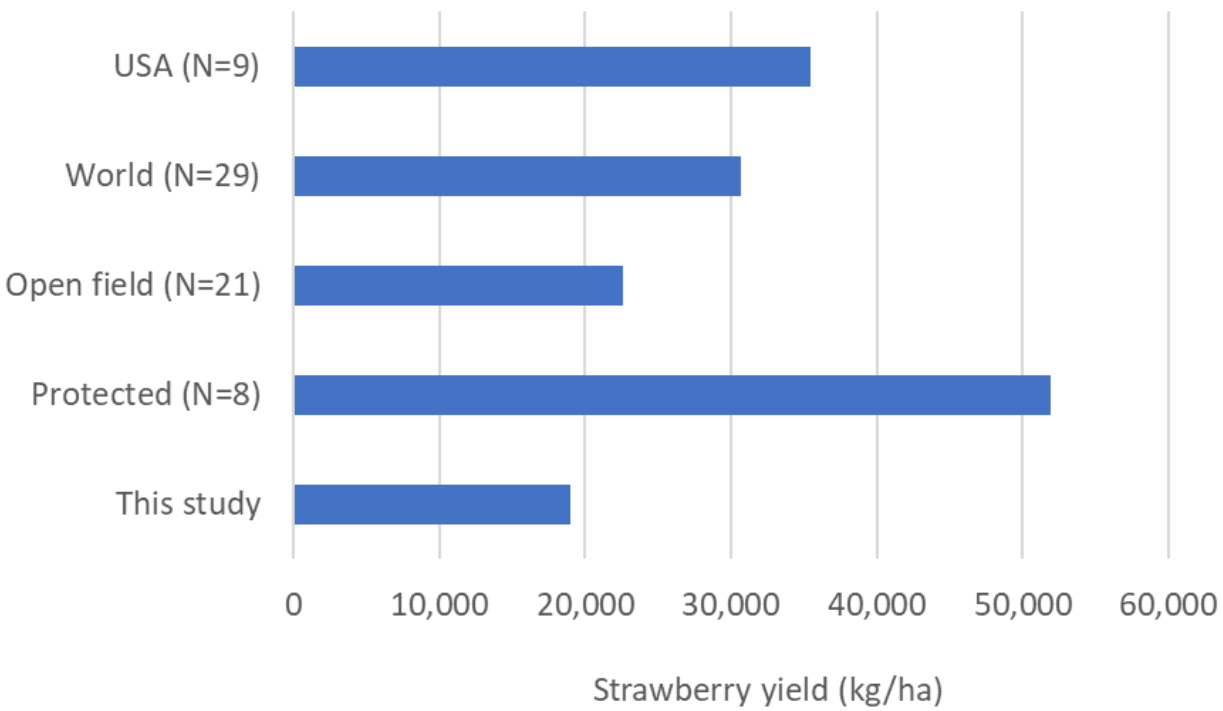

Figure 3. Comparison of the average strawberry yield in this study to yields ( $\mathrm{kg} / \mathrm{ha}$ ) reported in the USA, world, open-field systems, and protected systems using the data reported in Table 1.

\subsection{Global Warming Potential}

The GWP, estimated using the average yield over the two years, was $0.57 \mathrm{~kg} \mathrm{CO}$-eq per $\mathrm{kg}$ of strawberry fruit (Table 4). Aluminum manufacturing for the frame of the high tunnel accounted for the largest fraction of the total GWP, followed by the actual production activities (including human labor, assessed at $0.7 \mathrm{~kg} \mathrm{CO}_{2}$-eq per hour) and plastic manufacturing. The labor activities accounting for the largest fraction of production were harvesting and planting. Combined, these three factors accounted for over $70 \%$ of the total GWP. Adding in compost production, use of municipal tap water, and the purchased strawberry plugs (seedlings) brings the fraction of the GWP accounted for up to $90 \%$ of the total.

Table 4. Breakdown of the components contributing to the GWP of strawberry production for the defined functional unit.

\begin{tabular}{lll}
\hline Inputs/Emissions & GWP $\mathbf{( k g ~ C \mathbf { C } _ { \mathbf { 2 } } \text { -eq) }}$ & $\mathbf{\%}$ of Total \\
\hline Aluminum product manufacturing & 0.1714 & 30.03 \\
Production-direct activities, including labor & 0.1611 & 28.23 \\
Plastics manufacturing & 0.0808 & 14.16 \\
Compost, at plant & 0.0421 & 7.37 \\
Municipal tap water, at user & 0.0320 & 5.61 \\
Strawberry seedlings, for planting & 0.0255 & 4.46 \\
Gasoline produced and combusted, at equipment & 0.0153 & 2.69 \\
Manure, fertilizer, as applied N, at field & 0.0149 & 2.61 \\
Transport, light commercial truck, diesel-powered & 0.0107 & 1.87 \\
Extrusion, plastic pipes & 0.0041 & 0.72 \\
Agricultural machinery, general, production & 0.0031 & 0.54 \\
PVC pipe & 0.0030 & 0.52 \\
Compost, nutrient supply from compost & 0.0024 & 0.42 \\
Propane/ butane, at refinery & 0.0019 & 0.33 \\
Cooling operation, reefer & 0.0015 & 0.26 \\
Plastic tunnel construction & 0.0004 & 0.07 \\
Wire drawing, steel & 0.0004 & 0.07 \\
Peat production & 0.0002 & 0.03 \\
Total & 0.5706 & 100.0 \\
\hline
\end{tabular}


There is an even greater range of values reported for GHG emissions than for yields in strawberry production (Table 2). In comparison to the values reported in the literature, the system studied here generated lower levels of GHG emissions than might be expected. They were comparable to many of the values reported from the Mediterranean region, regardless of whether they were open-field or protected systems, and lower than those reported for the USA. Thus, despite having yields that were lower than average, this system performed reasonably well compared to the GWP of many other production systems in the USA and around the world (Figure 4).

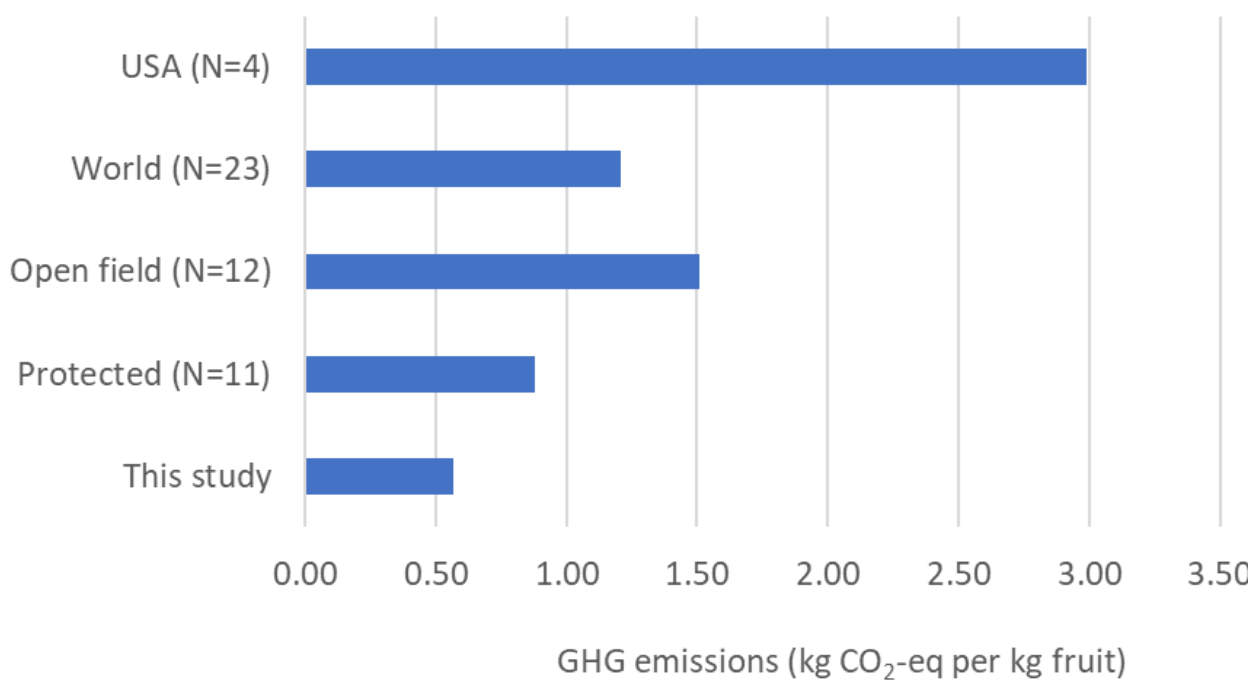

Figure 4. Comparison of the greenhouse gas emissions from strawberry production $\left(\mathrm{kg} \mathrm{CO}_{2}\right.$-eq per $\mathrm{kg}$ fruit) in this study to those reported in the USA, world, open-field systems, and protected systems using the data reported in Table 2.

\subsection{Discussion}

In summary, the average strawberry yield in this study over the two-year period (2020-2021) was much lower than the highest yields reported for commercial production (for example, California) but comparable to those reported for the southeastern USA. The GWP of $0.57 \mathrm{~kg} \mathrm{CO}$-eq per $\mathrm{kg}$ of strawberry fruit was lower than the values reported by Tabatabaie and Murthy [2] for four other states in the USA and more similar to those reported for various types of open-field and protected production in Spain, Italy, Turkey, and Iran (Table 2). Factors that may account for this situation include the use of an unheated high tunnel, the limited use of machinery and fossil fuels, and the absence of synthetic fertilizers.

A breakdown of the components contributing to the GWP of strawberry production in this study (Table 4) suggests that there is not much opportunity to reduce GHG emissions further, beyond obtaining higher yields with the same inputs. For example, eliminating the brief post-harvest refrigeration or sourcing plugs closer to the farm would do relatively little to reduce the overall GWP.

A recent comprehensive review of the environmental impacts of protected vegetable cultivation by Gruda et al. [26] drew from over 100 studies published globally since 1990 and summarized the findings of dozens of LCAs. They included simple plastic high tunnels [21], on the one hand, such as those found on the Berea College Farm, to high-tech PFALs, usually soilless culture systems with active climate control. The authors concluded that based upon current literature, PFALs have many advantages, but a reduction in GWP is not among them. In fact, they wrote the following about such systems: "A distinguishing feature ... is the large amount of energy consumption for heating during the cold season [and for] artificial lighting", and "... high amounts of GHG are produced and emitted from such protected cultivation systems". 
The construction of the facility itself contributes significantly to the overall GHG emissions, which must be included in the carbon footprint of the crops grown. The authors wrote that during "the production of the structure itself (using steel and concrete) high $\mathrm{CO}_{2}$ emissions are delivered into the atmosphere". This situation raises serious questions about the environmental costs and benefits of protected crop production, in particular, which practices and technologies can yield larger amounts of food without contributing more GHG emissions and exacerbating the climate crisis. As Gruda et al. [26] concluded, innovative adaptations are needed because currently "protected cultivation has some negative impacts on climate change".

\section{Conclusions}

This study evaluated the GWP of organic strawberry production under unheated high tunnels using LCA. Data were collected from two years of certified organic strawberry production in Kentucky, USA. The average strawberry yield was estimated to be 18,990 kg/ha, which is lower than yields reported for some commercial production but typical of conventional outdoor production in the region. This is an important consideration because the lower crop yields typically derived from organic production can often result in higher GHG emissions per unit product [27]. GWP was estimated to be $\sim 0.57 \mathrm{~kg} \mathrm{CO}_{2}$-eq per $\mathrm{kg}$ of strawberries, which mainly resulted from the aluminum and plastic structure comprising the high tunnel and direct emissions associated with crop production activities. However, the GWP was lower than values reported in similar studies, likely due to limited use of fossil fuels, as well as the absence of manufactured synthetic fertilizers. Future research should document and assess the GWP of strawberries produced in large-scale CEA or PFAL systems in the USA. This will permit comparisons to determine if the performance of such systems is an improvement over strawberry production in high tunnels and open fields with respect to GWP.

Author Contributions: Conceptualization, S.C.; methodology, S.C. and S.H.M.-A.; software, S.H.M.-A.; formal analysis, S.C. and S.H.M.-A.; writing-original draft preparation, S.C.; writing-review and editing, S.C.; project administration, S.C.; funding acquisition, S.C. All authors have read and agreed to the published version of the manuscript.

Funding: This research was funded in part by the Kentucky Horticulture Council as part of the "Kentucky Small Fruits Expansion Project" in 2022.

Institutional Review Board Statement: Not applicable.

Informed Consent Statement: Not applicable.

Acknowledgments: Assistance with data collection was provided by Victor Faluyi and Hallie Whitehead. Janet Meyer facilitated access to the field site and provided management and harvest records.

Conflicts of Interest: The authors declare no conflict of interest.

\section{References}

1. Wu, F.; Guan, Z.; Whidden, A. An Overview of the US and Mexico Strawberry Industries; IFAS Extension FE 971; University of Florida: Gainesville, FL, USA, 2015; (Reviewed December 2018); Available online: https:/ / edis.ifas.ufl.edu/fe971 (accessed on 30 June 2021).

2. Tabatabaie, S.M.H.; Murthy, G.S. Cradle to farm gate life cycle assessment of strawberry production in the United States. J. Clean. Prod. 2016, 127, 548-554. [CrossRef]

3. Samtani, J.B.; Rom, C.R.; Friedrich, H.; Fennimore, S.A.; Finn, C.E.; Petran, A.; Wallace, R.W.; Pritts, M.P.; Fernandez, G.; Chase, C.A.; et al. The status and future of the strawberry industry in the United States. HortTechnology 2019, 29, 11-24. [CrossRef]

4. Clark, S. Berea College (1871): The work college legacy. In Fields of Learning: The Student Farm Movement in North America; Sayre, L., Clark, S., Eds.; University Press of Kentucky: Lexington, KY, USA, 2011; pp. 31-50.

5. Kaiser, C.; Ernst, M. High Tunnel Strawberries; CCD-CP-61; Center for Crop Diversification, University of Kentucky College of Agriculture, Food and Environment: Lexington, KY, USA, 2019. Available online: http://www.uky.edu/ccd/sites/www.uky.edu. ccd/files/hightunnelstrawberries.pdf (accessed on 30 December 2021). 
6. Kateman, B. Carbon Labels Are Finally Coming to the Food and Beverage Industry. Forbes 2020. Available online: https:/ / www.forbes.com/sites/briankateman/2020/07/20/carbon-labels-are-finally-coming-to-the-food-and-beverageindustry / ?sh=4551e4567c03 (accessed on 30 June 2021).

7. Karst, T. Measuring Carbon Footprint Becoming More Common for Produce Companies. Packer 2021. Available online: https:// www.thepacker.com/news/sustainability/measuring-carbon-footprint-becoming-more-common-produce-companies (accessed on 30 June 2021).

8. Leach, A.M.; Emery, K.A.; Gephart, J.; Davis, K.F.; Erisman, J.W.; Leip, A.; Pace, M.L.; D'Odorico, P.; Carr, J.; Noll, L.C.; et al. Environmental impact food labels combining carbon, nitrogen, and water footprints. Food Policy 2016, 61, 213-223. [CrossRef]

9. Weber, C.L.; Matthews, H.S. Food-miles and the relative climate impacts of food choices in the United States. Environ. Sci. Technol. 2008, 42, 3508-3513. [CrossRef] [PubMed]

10. Soode-Schimonsky, E.; Richter, K.; Weber-Blaschke, G. Product environmental footprint of strawberries: Case studies in Estonia and Germany. J. Environ. Manag. 2017, 9, 564-577. [CrossRef] [PubMed]

11. Yildizhan, H. Energy, exergy utilization and $\mathrm{CO}_{2}$ emission of strawberry production in greenhouse and open field. Energy 2018, 143, 417-423. [CrossRef]

12. Khoshnevisan, B.; Rafiee, S.; Mousazadeh, H. Environmental impact assessment of open field and greenhouse strawberry production. Eur. J. Agron. 2013, 50, 29-37. [CrossRef]

13. Mordini, M.; Nemecek, T.; Gaillard, G. Carbon and Water Footprint of Oranges and Strawberries-A Literature Review; Federal Department of Economic Affairs FDEA: Bern, Switzerland, 2009; 26p.

14. Tittarelli, F.; Ceglie, F.G.; Ciaccia, C.; Mimiola, G.; Amodio, M.L.; Colelli, G. Organic strawberry in Mediterranean greenhouse: Effect of different production systems on soil fertility and fruit quality. Renew. Agric. Food Syst. 2017, 32, 485-497. [CrossRef]

15. Valiante, D.; Sirtori, I.; Cossa, S.; Corengia, L.; Pedretti, M.; Cavallaro, L.; Vignoli, L.; Galvagni, A.; Gomarasca, S.; Pesce, G.R.; et al. Environmental impact of strawberry production in Italy and Switzerland with different cultivation practices. Sci. Total Environ. 2019, 664, 249-261. [CrossRef] [PubMed]

16. Soode, E.; Lampert, P.; Weber-Blaschke, G.; Richter, K. Carbon footprints of the horticultural products strawberries, asparagus, roses and orchids in Germany. J. Clean. Prod. 2015, 87, 168-179. [CrossRef]

17. Romero-Gámez, M.; Suárez-Rey, E.M. Environmental footprint of cultivating strawberry in Spain. Int. J. Life Cycle Assess. 2020, 25, 719-732. [CrossRef]

18. ISO 14040:2006; Environmental management—Life Cycle Assessment—Principles and Framework. International Organization for Standardization: Geneva, Switzerland, 2006; 20p.

19. ISO 14044:2006; Environmental Management: Life Cycle Assessment. Requirements and Guidelines. Requirements and Guidelines. International Organization for Standardization: Geneva, Switzerland, 2006; 46p.

20. USDA Agricultural Marketing Service. National Organic Program Handbook: Guidance and Instructions for Accredited Certifying Agents and Certified Operations; USDA: Washington, DC, USA. Available online: https:/ /www.ams.usda.gov/rules-regulations/ organic/handbook (accessed on 5 January 2022).

21. Clark, S. Resource-use and partial-budget analysis of a transition to reduced-input and organic practices and direct marketing: A student-farm case study. J. Agric. Food Syst. Community Dev. 2014, 4, 113-130. [CrossRef]

22. IPCC. 2006 IPCC Guidelines for National Greenhouse Gas Inventories. 2006. Available online: https:/ /ipcc-nggip.iges.or.jp/ public/2006gl/ (accessed on 2 January 2022).

23. PRé Sustainability. SimaPro 9.1.1 What's New? 2020. Available online: https://simapro.com/wp-content/uploads/2020/10/ SimaPro911WhatIsNew.pdf. (accessed on 5 January 2022).

24. LTS. DATASMART LCI Package. 2021. Available online: https://ltsexperts.com/services/software/datasmart-life-cycleinventory / (accessed on 2 January 2022).

25. US EPA. Tool for the Reduction and Assessment of Chemical and Other Environmental Impacts (TRACI)-TRACI Version 2.1 User's Guide; Environmental Protection Agency: Cincinnati, OH, USA, 2012; 24p. Available online: https://www.epa.gov/chemical-research/ tool-reduction-and-assessment-chemicals-and-other-environmental-impacts-traci (accessed on 2 January 2022).

26. Gruda, N.; Bisbis, M.B.; Tanny, J. Impacts of protected vegetable cultivation on climate change and adaptation strategies for cleaner production-A review. J. Clean. Prod. 2019, 225, 324-339. [CrossRef]

27. Clark, S. Organic farming and climate change: The need for innovation. Sustainability 2020, 12, 7012. [CrossRef] 